Research, part of a Special Feature on Balancing Ecology and Community using Cumulative Effects Models

\title{
Social-Ecological Thresholds in a Changing Boreal Landscape: Insights from Cree Knowledge of the Lesser Slave Lake Region of Alberta, Canada
}

\author{
Brenda L. Parlee $^{1}, \underline{\text { Karen Geertsema }}^{2}$, and Allen Willier ${ }^{3}$
}

\begin{abstract}
Drawing on the traditional ecological knowledge (TEK) of the Lesser Slave Lake Cree, this paper shares understanding of how resource development has affected water, fish, forests, and wildlife as well as the well-being of Cree communities in the Lesser Slave Lake region of Alberta, Canada. In addition to descriptive observations of change, the narratives point to social-ecological thresholds or tipping points in the relationship of Cree harvesters to local lands and resources. Specifically, the study speaks to the echoing effects of ecological loss and degradation on traditional livelihood practices over the last 100 years highlighting the complexity of cumulative effects as well as the challenges of balancing resource development in the region with alternative land uses including those valued by Alberta's Aboriginal peoples.
\end{abstract}

Key Words: Aboriginal; ecosystem change; monitoring; traditional knowledge

\section{INTRODUCTION}

The trespassing of ecological thresholds can lead to rapid changes in social-ecological systems. Detecting such tipping points can be challenging particularly in complex environments facing multiple stressors. In western Canada, land use activities including agriculture, forestry, and oil and gas activity have increased significantly in recent decades. Research and monitoring in many parts of the province of Alberta point to an obvious and inverse correlation between the progress of resource development and declines in ecosystem health and the well-being of communities (Anielski 2001, Timoney and Lee 2001, Schneider et al. 2003, Nielsen et al. 2006). This paper attempts to further our understanding of these impacts of resource development from the perspective of Cree land users, i.e., elders and harvesters. More specifically, we discuss the relationship between the loss and degradation of natural resources and the ability of Cree in the Lesser Slave Lake region to sustain a traditional livelihood as defined here by the practices of hunting, trapping, fishing, and plant harvesting.

Our research is geographically situated in the Lesser Slave Lake region of northern Alberta (Fig. 1). The Cree, who have lived in this region for many generations, have developed a body of traditional ecological knowledge (TEK) that stems from repeated empirical observations of particular places, resources, and indicators over many life times (Berkes 2008). A wide range of academic studies have included TEK in the investigation of resource development effects. In Canada, there are many useful examples related to hydro-electric projects (Berkes 1982, Usher et al. 1992), commercial exploitation of forests and fisheries (Ommer et al. 2007, Stevenson and Natcher 2010), mining (Poirier and Brooke 2000, Witt and Hookimaw-Witt 2010), and oil and gas activity
(Nakashima 1990, Dana et al. 2009). The Hudson's Bay Program is a TEK study that explicitly focused on cumulative effects in that region (Sallenave 1994). One well-cited TEK study from western Canada is the Northern River Basin Study (Bill et al. 1996, Gummer et al. 2000). All these studies point to the value of TEK in our understanding of the echoed effects that ecological change can have on the way of life of Aboriginal peoples.

Fig. 1. Map of the study area: Lesser Slave Lake Region, Alberta, Canada.

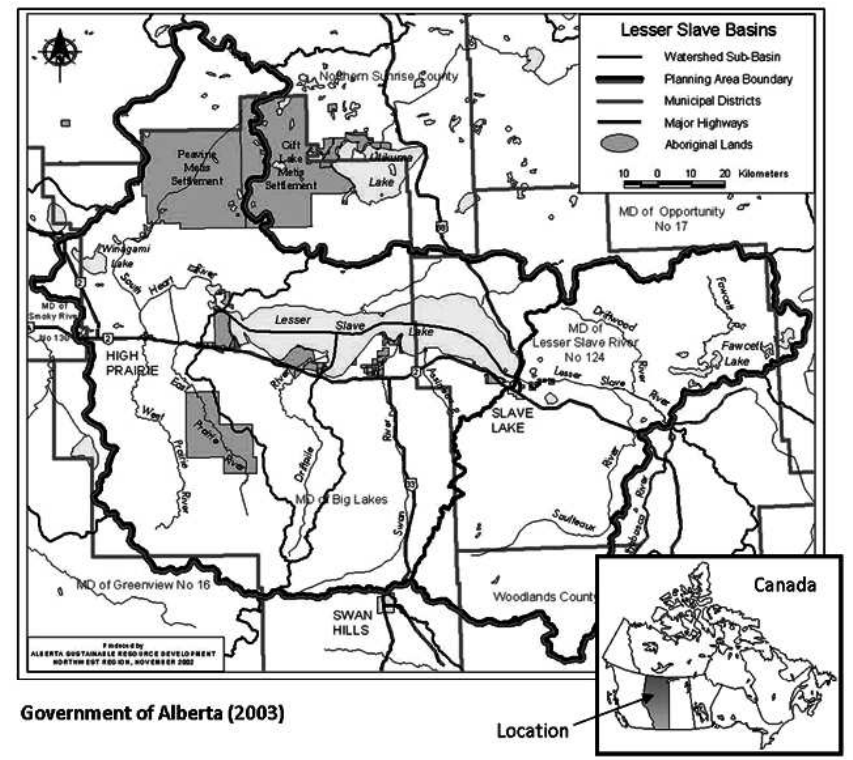


Guided by this literature, we argue that TEK of the Lesser Slave Lake Cree may be able to fill several key gaps in our understanding of the cumulative effects of resource development in this region of western Canada and furthermore may contribute to efforts to pinpoint thresholds or tipping points of both ecological and socioeconomic change. First, the long series of observation that has amassed over many generations may be particularly valuable in northern Alberta where there is little more than 50 years of good data on even the most highly valued of species (Stuart-Smith et al. 1997, McLoughlin et al. 2003). The earliest studies on woodland caribou (Rangifer tarandus-caribou) for example, date back to the early 1970s (Banfield 1974, Bergerud 1974). Datasets on water quality and Alberta fisheries are also less than 50 years old (Ryder 1965, Scott and Crossman 1973). There are other kinds of knowledge gaps that science alone cannot fill. The disciplinary nature of scientific research and the silos of regulatory decision making have led to a fragmented rather than holistic sense of change in the Lesser Slave Lake region. The integrated perspective offered by Cree elders and harvesters is a strength of this alternative knowledge system and is also arguably necessary for understanding the cumulative nature of environmental change.

Dealing with cumulative effects in this region is highly complex, not only because of the numerous kinds of development activities that have had antagonistic effects on ecosystem health over decades, but because of the diversity of views on what is a healthy ecosystem. What is healthy to one person is not necessarily so to another partly because of different geographic and socioeconomic positions. Farmers, sport fishermen, petroleum industry workers, and hunters are all likely to hold different views on what constitutes a healthy environment. For many indigenous peoples whose food, shelter, and other means of survival has always come from the environment around them, knowing what is healthy matters, not as a technical exercise, but because it constitutes survival. As noted by scholars in other regions, "People living directly from the land and water around them are acutely aware of indications that things are right or wrong with the natural world" (Usher et al. 1992:114). In the Denesoline (Chipewyan) community of Lutsël K'e, for example, elders distinguish between these two kinds of environmental changes; "edo" translates as "it changes" and "edo aja" translates as "something has happened to it" (Parlee et al. 2005). Where resource development activity has been relatively recent, land users may have an easier time unraveling the differences between edo and edo aja. In ecosystems with long histories of resource development such as northern Alberta, land users, similar to scientists, face a more complex social and ecological landscape.

The ways such complex changes are tracked may be viewed as more qualitative than quantitative; this is viewed by some as its strength. Although not precise, such a qualitative approach enables indigenous knowledge holders to consider and understand the interactions between larger numbers of variables in general fashion; Western science conversely tends to concentrate on a small number of variables quantitatively (Berkes and Kislalioglu Berkes 2009). Although empirically derived, some authors caution against the use of qualitative accounts of the past as containing misconceptions about environmental processes (Finlayson and Brizga 1995). On the other end of the spectrum are those who perceive TEK as without fault. "The acceptance of all TEK as infallible is an extreme position, almost as unfortunate as that of dismissing it" (Johannes and Lewis 1993:106). However, neither is western science infallible or objective in its storytelling. If one assumes that scientific accounts are similarly constructed understandings of change, i.e., not objective accounts, and can differ depending on the vantage point of those experiencing, measuring, and/or effecting such change, TEK holders are no more selective or subjective in their interpretations than those labeled as mainstream scientists. Neither are TEK holders homogenous in their perspective (Natcher and Hickey 2002); just as there are conflicting theories among scientists, elders can and do also disagree. These many and sometimes conflicting constructions of the past comprise a multifaceted and often messy story of ecosystem dynamics that can confound decision makers.

Within this mess of ecosystem change, it is nonetheless easy to see how some land use activities have become overarching drivers of ecosystem dynamics and others have been marginalized. Much of the resource development that has occurred in the Lesser Slave Lake region and other regions of northern Alberta has occurred with limited planning or attempt to accommodate the land and resource interests of Aboriginal peoples (Kennett 1999, Stevenson and Natcher 2010). The Government of Alberta has, however, recently committed to a land use framework that acknowledges the finite carrying capacity of watersheds, the air, and landscapes (Government of Alberta 2010). The identification of "appropriate thresholds" at regional and local scales that would guide decision making about future land uses are among the mechanisms of planning to be at play. What are appropriate thresholds? How will they be defined?

Ecological thresholds are described as the points at which a relatively small change in external conditions causes a rapid change in the structure or function of the ecosystem (Walker and Meyers 2004). Social-ecological thresholds similarly imply tipping points between relatively stable humanenvironment interactions and a new point of equilibrium. Given that social-ecological systems are linked, changes in one system may lead to impacts on the other resulting in echoed shifts in both ecosystem and social systems at many different spatial and temporal scales. 
Although agreeing on the importance of the concept, ecologists have, at the same time, viewed the identification of ecological thresholds as problematic. TEK may be able to help address this problem in a number of ways. The absence of local scale and long-term data about ecosystem dynamics is one underlying issue that TEK might help address; in many indigenous communities there is a large pool of available empirical data resulting from repeated and systematic land and resource use that has accumulated over the last half century and more. Ecological events or system changes that occurred earlier than the 20th century may also be present within the social memory of the community (Berkes 2008). Previous studies aimed at documenting the oral histories in which such events are recorded or interpreting previously documented TEK can reveal much about the patterns of ecosystem change; in Alberta the Northern River Basin Study is among those most relevant (Bill et al. 1996, Gummer et al. 2000). Because ecological and social systems are linked, the crossing of an ecological threshold will necessarily leave a socioeconomic footprint. Tracking land user perceptions and use of natural resources valued by the community over time is one way of accounting for this footprint, particularly if such studies include queries about the underlying causes of changes in such perceptions and use. Harvest studies, dietary intake studies, or land use and occupancy research provides a secondary basis of data on which to construct models of social-ecological change.

It may also be possible to identify thresholds before they occur. Societies whose livelihoods depend on the security of healthy resources are thought to be particularly attuned to triggers of regime shift. They have been described in other contexts as "adaptive experts" whose explicit, implicit, and tacit knowledge of ecosystems provides them with the capacity to "recognize emergent properties of the system and make good predictions even though they might not always be able to explain precisely how they do it" (Fazey et al. 2006:25). As an example, elders and land users in the Athabasca River Watershed who have experienced rapid declines in the health of water and fish populations due to oil sands development have called a halt to further consumption, use, or effluent discharge into the river system (Tenenbaum 2009). In other regions, calls to stop development or make it more sustainable are increasingly commonplace; although some may see these merely as political actions, they also represent an informed understanding that many environments can no longer withstand the pressures of clear-cutting, commercial fishing, mining, or urban sprawl without significant ecological and socioeconomic consequence (Agyeman et al. 2009).

In summary, this research paper asserts that the knowledge of the Lesser Slave Lake Cree may be useful in helping us understand both historic and contemporary issues of environmental change as well as their socio-cultural implications. This combined social-ecological perspective is a critical ingredient in emerging land use planning processes. By telling their stories TEK holders are also making sense of and articulating meaning about what is going on in their social and ecological worlds. "The features we distinguish in the landscape, the kinds of changes we observe taking place, and our attribution of the causes of change, all relate somehow to who we are and what our life experiences in that place have been" (Lane 1997:203).

\section{STUDY AREA}

The Lesser Slave Lake Cree currently occupy the southern edge of present day Peace River watershed known as "unchaga" or Peace in Cree (Fig 1). Unchaga is thought to refer to a treaty developed between the Cree and the Beaver peoples over lands and resources with the Peace River forming the boundary of neutrality. Like other Woodland Cree, their livelihood was and continues to be closely connected to the seasonal availability and health of species such as woodland caribou, moose (Alces alces), elk (Cervus canadensis), wood bison (Bison bison athabascae), white-tailed deer (Odocoileus virginianus), fish, and small mammals such as beaver (Castor canadensis), hare (genus Lepus), and muskrat (Ondatra zibethicus). The main fur-bearing animals were beaver, mink (Neovison vison), marten (Martes americana), otter (Lontra canadensis), lynx (Lynx canadensis), fox (Vulpes vulpes), and muskrat (Smith 1981).

Indigenous peoples have occupied the Lesser Slave Lake region for at least a thousand years. The Lesser Slave Lake Cree are considered part of the Indigenous Western Woods Cree who have occupied the boreal forest in Alberta since the mid-18th century (Smith 1987). The Woodland Cree historically originated from around the Hudson's Bay region. As the population grew and resources became more limited, the population is theorized to have expanded further west (Smith 1987). Many ethnographers time the movement of the Cree into western Canada with the expansion of the fur trade. The skill of Cree as hunters and trappers made them a valued ally to the Hudson's Bay Company and Northwest Company who established posts in the region in the early 1800 s. Lesser Slave Lake was a strategic settlement area for the Beaver and Cree not only because of the abundance of local resources but because of its position relative to the Peace River watershed and consequent links to the Slave and Mackenzie Rivers. It became a particularly important location during the fur trade; posts were established at the west end of the lake by both the Northwest Company (1801) and then Hudson's Bay Company (1815). The two posts were later amalgamated in 1821 .

In 1899, the Cree of this region became signatories of Treaty \#8, which was to protect their rights and interests in the lands and resources "so long as the waters run and the sun shines on us", as described then by Chief Keenooshayo of the Cree who met at Lesser Slave Lake to negotiate the Treaty (Chief Keenooshayo, as cited in Mair 1999:60). These rights to hunt, 
trap, and fish were not only enshrined in the Treaty but were later affirmed in the Natural Resources Transfer Agreement (1930), which stated that the province would "secure to the Indians of the Province [of Alberta] the continuance of the supply of game and fish for their support and subsistence" (Tough 2003:1000). Although there is much legal debate on the meaning of such terms, it is sometimes forgotten that this was more than an economic issue; such provisions had and continue to have much greater meaning, "for the Indian loves his way of living" (Chief Keenooshayo, as cited in Mair 1999:60). The ability of the Cree and other Aboriginal peoples of Treaty \#8 to maintain that way of living, i.e., a traditional livelihood, however, would become increasingly difficult as settlement continued and resources were developed in the region throughout the 20th century.

The first 20 years following the signing of the treaty saw little change in livelihood practice. "In 1908, most northerners lived pretty much as they had prior to the time of the settlement, either within or outside their assigned holdings" (Mair 1999: xvi). This shifted abruptly with the opening of the Dominion Land Office in Grouard in 1909, which saw a boom in agricultural settlement and the subsequent approval of a railway project linking Edmonton to the Fort McMurray area and its waterways and Peace region by 1921. "These developments brought an influx of Euro-Canadian developers whose views on the exploitive possibilities of the land stood in stark contrast to those of people who subsisted with the environment" (Leonard, as cited in Mair 1999:xvii).

The area was a key transportation hub initially by waterway and later by road and rail. The development of the highway north during the post-World War II era was significant in linking the area to Edmonton and Calgary further south and to resources to the north. The rise of agricultural commodity prices in the 1950s and the comparative availability of 'cheap land' led to further expansion of what was considered by the province as one of the last agricultural frontiers. Wheat became the principal cash crop of the region, however, other crops such as legumes, alfalfa, and pasture land for cattle were also on the rise during this period (Vanderhill 1963). The Veterans Act facilitated the arrival and homesteading of hundreds of demobilized service men returning from World War II. Many of the tracts of land were not well suited to agriculture, however, which meant little success for new farmers.

There is also a long history of commercial fishing on Lesser Slave Lake itself dating back to the early 1900 s with the most important species historically being lake whitefish (Coregonus clupeaformis), lake trout (Salvelinus namaycush), and cisco (Coregonus artedii). Because of pressure from commercial fishing trout were extirpated by the mid-1940s. Mink farming added further stress to the fish stocks. The small nets used by mink farmers to catch small feed fish (cisco) for their operations, negatively impacted on many other lake species including whitefish and walleye (Sander vitreus), which collapsed and did not recover until the late 1980s well after the small-mesh cisco fishing was closed in 1972 (Mitchell and Prepas 1990). Mink farming all but ended in the late 1970s because of the loss of cisco and lower demand for mink furs. Currently whitefish comprise over half of the catch of a small commercial fishery. Sport fishing also accounts for a significant portion of the catch of walleye, yellow perch (Perca flavescens), and pike (Esox lucius; Mitchell and Prepas 1990). Subsistence fishing is no longer viable because of these pressures.

The discovery of oil at Swan Hills in 1957, the third largest deposit in Canada, began a wave of exploration similar to that following the 1947 Leduc discovery that started the postwar oil boom in Western Canada. Air photos from 1949 to 1991 at Swan Hills reveal the resulting change in landscape fragmentation because of roads and seismic lines (Fig. 2). A key peak in gas exploration took place between 1970 and 1976. The total number of leases in eastern Alberta climbed significantly during this period (Schneider et al. 2003). By the 1980s, however, the Government of Alberta developed and implemented policies aimed at reinvigorating a downturned rural economy. Alberta's forests became the subject of extensive and "unprecedented state sponsored expansion by the pulp and paper industry" (Tupper et al. 1992:40). Most of the expansion was linked with the construction of mega pulp mills including Daishowa Canada at Peace River and the Alberta Pacific (ALPAC) mill at Athabasca. Resurgence of the oil and gas exploration in the 1990s led to further loss and degradation of wildlife habitat in the region.

Fig. 2. Aerial photos of change in the study area: Swan Hills 1949, 1964, 1982, 1991.
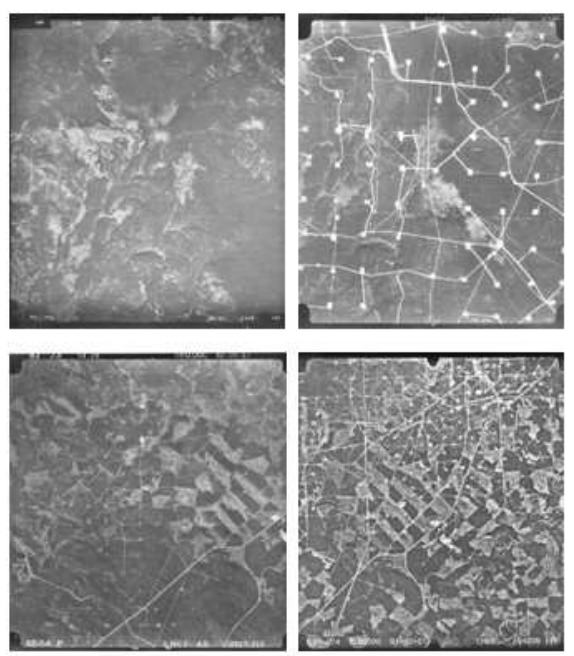
The Swan Hills Waste Treatment Centre was developed just west of Swan Hills in 1987 to provide hazardous and special waste treatment services for Alberta. A mechanical failure of a transformer furnace occurred on 16 October 1996 and resulted in the release of an unknown quantity of polychlorinated biphenyls (PCBs), dioxins, and furans into the surrounding environment. Following the incident the provincial government issued a health advisory recommending limiting the human consumption of wild fish ( $6 \mathrm{oz} / \mathrm{week})$, and wild game (13 oz/month) harvested within a $30 \mathrm{~km}$ radius of the site. In 2009, another leakage, initially not reported or investigated by the Government of Alberta, further compounded local concerns about contaminants in the regional ecosystem (Baxter and Lee 2004).

Oil and gas exploration continues to be significant in the Swan Hills, Mitsue Lake, and Marten Hills areas and within Lesser Slave Lake Provincial Park. Currently, there are hundreds of oil/natural gas wells, active and inactive, in the drainage basin (Fig. 2), particularly in the southeastern region. The majority of land zoned for agriculture lies within the Driftpile and Swan River deltas and in the Joussard - High Prairie - Grouard triangle to the west of Lesser Slave Lake. There are approximately 189,445 ha of farm land (436 farms) in this area. The forest management zones in the Lesser Slave Lake region are primarily managed by the Slave Lake Pulp Corporation (629,284 ha), which harvests for spruce (Picea spp.), aspen (Populus spp.) and pine (Pinus spp.). The Forest Management Plan for the area estimated an annual allowable cut for all deciduous trees at 588,832 $\mathrm{m}^{3} / \mathrm{yr}$, and for all coniferous trees at $369,043 \mathrm{~m}^{3} / \mathrm{yr}$ (Alberta Sustainable Resource Development 2003). The Annual Allowable Cut (AAC) for the Lesser Slave Lake area is approximately 1 million $\mathrm{m}^{3}$ (Alberta Sustainable Resource Development 2003, Thormann et al. 2008)

Together these activities introduced a profound set of changes on local and regional ecosystems. The specific details and nature of those cumulative effects are, however, little understood. It is in this context that research with Lesser Slave Lake Cree communities was carried out.

\section{METHODS}

The research was developed collaboratively between the Lesser Slave Lake Indian Regional Council (LSLIRC) and the University of Alberta with funding from the Sustainable Forest Management Network. Terms and conditions for the research were set out in a research agreement between LSLIRC, the researchers, and the funding agencies. Semidirected interviews were carried out by a graduate student (second author) and a local research assistant.

Twenty-three interviews were carried out with Cree land users from the five study communities (First Nations). Of the 23 interviewees, four were female, sixteen were male, nine were in their $50 \mathrm{~s}$, seven were in their $60 \mathrm{~s}$ and four were between the ages of 70 and 90 . The focus was on knowledge gathered through land-based activities including traditional activities such as hunting, fishing, trapping, berry harvesting, and medicinal plant gathering. We also sought to interview members of the Cree communities engaged in more contemporary land-based activities including forestry activity, tourism, recreation, agriculture, and those employed by the local community councils as environmental monitors and land and resource managers.

An initial set of interviewees were identified by the LSLIRC as land experts in particular regions of the traditional territory. Subsequent interviewees were identified through chain referral methods, e.g., snowball sampling, or by recommendation of resource staff with the LSLIRC. The graduate student researcher was supported and guided by a local LSLIRC research staff person who was carrying out related research on the environmental and health effects of the Swan Hills Waste Treatment Centre with funding from Health Canada. All the respondents self-identified as Cree or members of one of five First Nations in the region. Interview questions focused on interviewee land use patterns, e.g., place and practices, knowledge of ecological change, i.e., key indicators, place, time, and species, and about the practices or ways in which knowledge about ecological change is generated. Where possible all observations were temporally referenced and mapped with interviewees on 1:250,000 and 1:50,000 scale maps. The focus on cumulative effects was not explicit in the interview guide; rather our understanding of cumulative effects was constructed after the interviews were completed based on what was told about ecosystem change with respect to specific indicators, i.e., signs of change, in places and species over time.

Analysis took place in three phases. The first analysis involved correlating the data on land use practices with observations of change. We looked for data that were empirically based, i.e., an observation or experience of the interviewee, or were grounded in TEK, e.g., knowledge passed on from previous generations. Shared knowledge, e.g., observations shared by family members or peers, was also highlighted as valuable to the study. The second phase of analysis involved organizing the data around key themes of environmental change in places and species valued by interviewees and specific time periods. The time span for the majority of observations is 1950-2006 with many interviewees referencing their own observations, experiences, or oral histories about environmental change during an early period of roughly 1930-1950. The final stage of analysis involved constructing the model of cumulative environmental effects (Table 1, Fig. 3). This model was based on interviewee narratives on perceived correlations and/or patterns of cause-effect between resource development activities and observed ecological change. Theories on cause and effect were embedded in many of the narratives. These associations were not sought by the researcher but rather 
Table 1. Key themes and indicators and resource development issues.

\begin{tabular}{|c|c|c|}
\hline Component & Indicator of Change (Observations) & Primary Concern \\
\hline Water quantity & $\begin{array}{l}\text { water levels in Lesser Slave Lake } \\
\text { wetland streams, creeks drying up } \\
\text { flow interruption and change } \\
\text { extreme events - flooding }\end{array}$ & $\begin{array}{l}\text { forestry } \\
\text { oil and gas activity } \\
\text { climate change }\end{array}$ \\
\hline Water quality & $\begin{array}{l}\text { sediment loading/turbidity } \\
\text { color (rust, green, black) } \\
\text { smell } \\
\text { algae bloom } \\
\text { contaminants }\end{array}$ & $\begin{array}{l}\text { forestry } \\
\text { oil and gas activity } \\
\text { contamination from the Swan Hills Waste Treatment Centre }\end{array}$ \\
\hline Fish & $\begin{array}{l}\text { body condition (e.g., skinny fish) } \\
\text { contaminants } \\
\text { population (abundance by catch per unit effort) } \\
\text { population diversity (loss of key species) } \\
\text { movements } \\
\text { health of spawning areas } \\
\text { number of fishers/anglers } \\
\text { access by Aboriginal harvesters }\end{array}$ & $\begin{array}{l}\text { farming (historic mink farming) } \\
\text { habitat loss or degradation due to forestry, oil, and gas } \\
\text { contamination from the Swan Hills Waste Treatment Centre }\end{array}$ \\
\hline Forest Resources and Habitat & $\begin{array}{l}\text { number/access to berry harvesting sites } \\
\text { color and productivity of species } \\
\text { medicinal plants } \\
\text { forest habitat loss }\left(\mathrm{km}^{2}\right) \\
\text { vegetation diversity } \\
\text { salt licks used by moose } \\
\text { Contaminants }\end{array}$ & $\begin{array}{l}\text { agriculture } \\
\text { forestry } \\
\text { oil and gas activity } \\
\text { contamination from the Swan Hills Waste Treatment Centre } \\
\text { climate change }\end{array}$ \\
\hline Moose & $\begin{array}{l}\text { body fat } \\
\text { fat around the organs (i.e., kidneys) } \\
\text { antler deterioration } \\
\text { bone deterioration, } \\
\text { lesions (e.g., dark spots on lungs) } \\
\text { cysts in liver/hide (resembling warts) } \\
\text { contaminants }\end{array}$ & $\begin{array}{l}\text { habitat loss and contamination due to oil and gas activity } \\
\text { contamination from the Swan Hills Waste Treatment Centre } \\
\text { Unknown }\end{array}$ \\
\hline Air quality & Smell & oil and gas activity \\
\hline
\end{tabular}

emerged as a predominant theme in response to other questions. Excerpts from these narratives are included in the paper to help address the issue of disembodiment or decontexualization of information and observations that inevitably results in written reporting of local and TEK.

\section{RESULTS}

The narratives collected during interviews dealt with many aspects of environmental change. There were many possible categories that could have been used to organize what was shared; among them is the category of place, which would have been more consistent with how these changes were discussed by interviewees. For the purposes of this paper, however, we use the categories of land, water, fish, forests, and wildlife to talk about ecosystem change, and their echoed effects within Cree communities to talk about social system change. These categories were perceived by the authors as a more accessible way of communicating results to a broader audience unfamiliar with the region.

\section{Ecosystem changes} Water quantity

A dominant issue of concern was related to water levels in Lesser Slave Lake, which have changed dramatically in recent years. Harvesters in the region have noted abrupt dropping of water levels in the lake since the early 1990s (Interview \#17, 17 November 2006). The change was defined as one not seen before or one that could not be attributed to natural variability. Interviewees attributed cause to development activity in the region, specifically clear-cutting in the watershed, overconsumption of lake water by water license holders, e.g., industrial users, as well as climatic factors including rising temperatures.

A related set of observations focuses on the drying up of streams, creeks, and wetlands. As noted by one interviewee, drying up of many areas is a new phenomenon "never seen before" (Interviewee \#22, 8 November 2007). 
Fig. 3. The figure summarizes the perceived causes of change in the regional environment with echoed effects in the social system (traditional use and well-being). These social changes are described here as having further feedbacks within this system as changes in traditional harvesting in turn influence what, where, and how harvesters observe both in relation to the stresses created by resource development as well as changes in the environment directly.

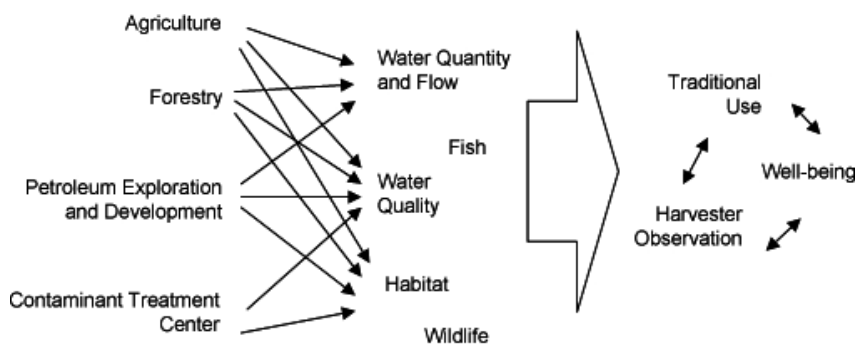

The wetlands are drying up. This problem is because it's got a lot to do with the climate as well but definitely the open land area [clear-cutting] ... there's a little muskeg in that area adjacent. That's dried up because of the clear-cut operations. (Interview \#2, 20 October 2006)

Flow change is also a related concern. One interviewee commented on how clear-cutting and road development has changed or interrupted stream flow in many areas where he used to go hunting.

\section{It's only when you are really hunting in the bush you can see [the impact] because you can see all these roads they've built out there, and you see some of the natural watercourses that are now diverted by these roads so some areas where there was a lot of water. (Interview \#22, 8 November 2007)}

Another major issue is related to the fixed-crest weir and eight cut-off channels of the Lesser Slave Lake Regulation Project constructed in 1987 that was intended to reduce the severity of flooding of low-lying areas around the lake. Although the regulation project stabilized flooding in some areas, the construction also decreased flow and water levels with resulting consequences on water quality and fish habitats such as spawning areas.

The predominant theme in observations and concerns on water quantity was flooding. The following interviewee described how flooding has increased over the last two decades. The excerpt describes how and why flooding has increased as a result of forestry and oil and gas activities.
Before the development, you would know if there was a flood [coming], you knew in advance because it was a slow process. Now today if you have a flood, it could happen within an hour, two hours, you know, from the river coming up over its banks, and that's because the runoff now is so fast. There's a large amount of trees that have been clear-cut in our watershed areas which now increases our, the risk in terms offlash floods. (Interview \#1, 20 October 2006)

These changes in water levels, flow, and flooding are identified as relatively recent changes in the Lesser Slave Lake region. Although these effects are issues in and of themselves, they also contribute to other kinds of ecological changes including those related to water quality.

\section{Water quality}

The quality of water in the region was a concern for most interviewees. Many used potability of bush streams as the main indicator of water quality.

\section{When I was younger you can go out in the bush and, you know, you can eat off, you can drink off of the stream ... or you can go to a muskeg, dig a hole and get fresh water. You wait a little bit till it clears, then you can drink from there. Now ... the water just tastes bitter. It is black. (Interview \#3, 12 October 2006)}

Other interviewees talked about the color of water in lakes and streams as the key indicator. Although there were many concerns about the greening or eutrophication of the Lesser Slave Lake and surrounding lakes, interviewees also shared observations of black and rust colored water. "There's a lot of rust colored water in just about all the streams out there" (Interview \#22, 8 November 2010). The discoloration of the water was also associated with dirty, murky, or turbid water issues. In some cases the concerns related to water diversion into Buffalo Bay in western Lesser Slave Lake. Sediment loading in streams and rivers caused by runoff in clear-cuts was also a major issue.

\section{Fish health and populations}

Overfishing in Lesser Slave Lake during the mink farming era remains a persistent concern for many residents who grieve the loss of the fishery that existed prior to the 1940s. The growth in tourism and angling on the lake is perceived by some as compounding this problem and limiting the recovering and rejuvenation of fish stocks.

Concerns about water quantity and quality have implications for fish and their habitat, particularly those fish valued as traditional food. Contamination of lakes, streams, and rivers from the Swan Hills Waste Treatment Centre was a cause of concern for those who traditionally harvested in the region. As noted by one interviewee, "we still have a $30 \mathrm{~km}$ radius 
that there is a warning not to consume too much wild meat, let alone even try and eat the fish" (Interview \#2, 2 October 2006).

Fish movements and access to spawning areas was another key indicator of change noted by interviewees.

Today I don't know if [the fish] even go $10,15 \mathrm{~km}$ south of the lake because of the obstructions that they have to face, they don't survive as well when they go to their spawning areas and that's due to the type of [development occurring]. (Interview \#2, 2 October 2006)

Given this history of overexploitation, some interviewees were highly critical of provincial government efforts to regulate Aboriginal fishing activities under the guise of sustainable development.

\section{Forest habitat and resources}

Observations of change in forest ecosystem health were shared during interviews. These discussions focused on seven kinds of edible plants as well as medicinal plants. Among the key concerns was the loss of traditional berry patches. These losses are largely attributed to clearing and drying out of the land associated with development as well as climatic factors. Other residents talked about a discoloration of berries and plants that they had not observed or experienced before. A related concern was around loss and deterioration of wildlife habitat and the lack of respect and value placed on animals in the context of forestry operations. Other interviewees offered a longer term perspective and held perceptions that the forests would come back if left alone.

\section{Moose population and health}

Cree have depended on many kinds of small and larger wildlife in the region as traditional food for many generations. Interviewees shared many observations and experiences related to small mammals, e.g., rabbits and muskrat, and wolves, deer, and birds. The predominate focus was on moose health and population decline, and the most detailed observations and discussion related to these issues. A key issue was the population and age structure of these animals in the region.

\section{It's very rare that you actually can find a big moose. You know, most of the game now, are very, very young...judging from the age of the moose, it's pretty obvious that the moose's lifespan isn't very long. (Interview \#3, 12 October 2006)}

One of the key indicators of moose health was changes in body condition including body fat. Several hunters offered very detailed observations about fat around the chest and brisket suggesting it should be more than one to two inches in the fall but "nowadays you are lucky if you see a quarter inch of fat on them" (Interview \#6, 22 September 2006). There were also extremely detailed observations about internal signs of health or good body condition.

\section{I would say the kidneys buried within a minimum of two inch to three, four inches of fat around the kidney [is normal]. That is what I recall in the mid-70's. That's when I did a lot of hunting. Today you'll see its skinny, I call it skinny kidney because a portion of that kidney itself is visible. (Interviewee \#2, 20 October 2006)}

\section{Social system changes}

These ecological changes were not described in isolation but were embedded within narratives that spoke to the social, economic, cultural, and health implications. For many harvesters, the changes witnessed in the environment have increased their perception of risk or worry that wildlife is no longer safe to eat. This elevated risk has led some to curtail their hunting activities and depend more heavily on store bought sources of meat. As clearly articulated by one interviewee “...there's nowhere to hunt anymore ... It's getting worse anyway. Every year it gets worse and worse 'cause they keep taking more and more" (Interview \#6, 22 September 2006). For those who continue to harvest, the "worry" has led to an increase in vigilance in their observations as noted by interviewee below.

We had no worries about that, at least 20 years ago,
and prior to that waste treatment plant being open
out there. We had no worries we would just go out
there, and we would harvest, and we would look at
the liver and it would be just perfect. Now we are
constantly watching every moose we get... We check
all the organs out and we check for growths and we
will check even to see how the moose is just standing
there [behavior], or if he's walking away, if he's
weak, or if he has a shiny coat. Like you can just tell
by looking at them, so if there's something wrong
we'll know it. But, I know a long time ago, definitely
we didn't have no worries out there. (Interviewee
\#22, 8 November 2007)

The perceptions that the environment is no longer healthy and that moose may not be healthy to eat have led to worries about human health as well.

It's hard on your mind, and it's hard on your body, because every moose you shoot you hope that it is good, and you hope you don't get sick... It has affected us mentally, and health-wise there seems to be more cases of cancer, and more cases of diabetes. Something is definitely happening out there, and this was not happening to us before. (Interviewee \#22, 8 November 2007) 
In addition to these socio-cultural and economic concerns, several interviewees noted the deeper feelings of loss or grief experienced by community members including young people.

\begin{abstract}
We have a lot of our young people who do not even go into the Swan Hills area because of the waste treatment plant [Alberta Waste Treatment Centre] they just absolutely refuse to. So, not only health wise, but I guess it has also affected their spirit ... There's no more socializing out on the land, and being in touch with nature; just having a good time out there, you know? (Interview \#6, 22 September 2006)
\end{abstract}

There are clearly many kinds of responses to ecological conditions that include shifts in the location and species of resources harvested. There are also many less quantifiable effects on well-being that have also been detailed by the elders and harvesters of the Lesser Slave Lake region.

\section{DISCUSSION}

“... your forest and river life will not be changed by the treaty ... as long as the sun shines and the earth remains." (Treaty Commission for the Federal Government at the signing of Treaty \#8 at Lesser Slave Lake 1899, as cited in Mair 1999: xxxiv)

Despite assurances to the contrary made at the signing of Treaty \#8, the Lesser Slave Lake region has undergone significant change over the last century. Can TEK contribute to our understanding of past environmental conditions? What role might TEK place in the development of "appropriate thresholds" for current and future land use planning?

\section{Learning about past ecological conditions}

Looking back can be instrumental in understanding the present and the future of environmental change. For many regions of Canada, mainstream scientists have a relatively short time series of data on which to construct the past when compared to TEK holders whose observations extend over many lifetimes. Given that time and resources for our study were limited, assertions that TEK adds value to the scientific record for the Lesser Slave Lake area are cautiously made. No analysis of the scientific record was undertaken to identify gaps or to compare with the results of this study. It is anticipated, however, that there are many gaps in scientific data during the period preceding the 1960s that can only be addressed through further TEK research.

There are many references in the narratives to conditions worsening in the "last 10 years," which may be explained by the interviewees' ability to more easily recall recent observations relative to those of earlier years. Such emphasis may also speak to the additive and compounding nature of cumulative effects. It would make sense that as the pace and scale of resource development has increased, so too has the evidence of environmental change. Many different kinds of changes are highlighted in the excerpts shared in this paper. In some incidents, interviewees speak of new and unknown phenomenon, e.g., contaminants; in other circumstances the change is known but is now being perceived as larger in scale, frequency, duration, or severity, e.g., forest fires and flooding. Few if any of the observations made were explicitly or implicitly framed as positive or synergistic with Cree land values or land uses. The tendency to identify or emphasize what is wrong or "not right" in the environment is arguably a purposeful bias that historically would have guided harvesters away from potentially threatening circumstances and may continue to serve this purpose.

The researcher encouraged interviewees to associate specific ecological observations with a place, their age, a historical event, and/or a specific year and season. Although some observations were spatially and temporally generalized, in other cases elders and harvesters were far more specific. Details about the indicator(s) of change were also important. As an example, interviewees who said the health of moose was changing were asked about the specific signs that would indicate this change. Many different signs were given as examples, e.g., "skinny kidney." These indicators are illuminating of the ways that Cree track environmental change in their region (Table 1).

The narratives also point to perceived causes of the changes observed (Table 1). Although not empirically driven in all cases, the perspectives on cause offered by elders and harvesters in this study may speak to aspects of ecosystem dynamics less understood by mainstream science. Questions of cause-effect have in other TEK studies been highlighted as oversimplifications of what elders describe as complex phenomena (Berkes et al. 2001, Omura 2002). In this context, the emphasis on perceived cause may stem from a sense of stewardship or responsibility that the Cree may feel in respect of the protection of the land for future generations. For although this region is indeed a complex system, there are also many obvious and clear solutions related to the problems identified by elders and harvesters in this study.

Figure 3 summarizes the perceived causes of change in the regional environment with echoed effects in the social system, i.e., traditional use and well-being. These social changes are described here as having further feedbacks within this system as changes in traditional harvesting in turn influence what, where, and how harvesters observe both in relation to the stresses created by resource development as well as changes in the environment directly.

\section{TEK and social-ecological thresholds}

Accounts from the period following the signing of Treaty \#8 in 1899 suggest there was little change in the livelihood of the Cree for a decade after the Treaty was made. As noted by Leonard in his analysis of the writings from this period, this 
all changed abruptly by 1910 (Leonard, as cited in Mair 1999). Since that time, there have been many kinds of changes in ecological conditions that have led to echoed effects in harvesting practices and the well-being of the community. These echoed effects comprise what resilience scholars would describe as fast feedbacks, e.g., changes in where and what is harvested from one season to the next, and slower feedbacks, e.g., changes in values, knowledge, and capacity to harvest.

In figure 4, the total value from land use, whether resource development or traditional harvesting, in the Treaty \#8 region is represented on the y axis. A conceptual timeline is shown on the $\mathrm{x}$ axis. Since the signing of Treaty $\# 8$ in 1899 , lands have increasingly been alienated away from traditional uses of hunting, fishing, trapping, and related harvesting activities and have been "taken up" (as described in the language of the Treaty) for other uses defined by the state (Fig. 4a). The heuristic suggests that traditional land use patterns may have been relatively noncompetitive with resource development during the early period of settlement (Fig. 4b-c). However, the capacity of harvesters to sustain such a traditional livelihood was inevitably surpassed (Fig. 4d) with increased development and impacts on resource availability (RAV), which is defined here as a function of resources quality (RQ), physical and institutional access (RAC) with feedbacks on capacity, i.e., knowledge and skills for resource harvesting ( $\mathrm{CRH}$; (c-e). F $=\mathrm{RAV}\left(\mathrm{RAB}, \mathrm{RQ}, \mathrm{RAC}_{\mathrm{P}}, \mathrm{RAC}_{\mathrm{I}}\right),(\mathrm{CRH})$.

The narratives also speak to social-ecological limits. Statements such as, "I can no longer drink the water at," "there is nowhere to hunt anymore," "we would never fish in this area" are clear indications of tipping points in the relationship of the Cree to the land around them. On the whole, the traditional livelihood appears no longer viable in many areas of the Lesser Slave Lake region because of the loss and degradation of natural resources valued by the Cree. In some cases, this is due to acute and site-specific events such as the spill at the contaminant treatment facility or in other cases to the more widespread and amorphous problems of clearcutting. The factors influencing the tipping point, or the belief and practice that harvesting is no longer viable is talked about by elders and harvesters in many different terms including resource abundance (RAB), resource quality (RQ), institutional/physical access $\left(\mathrm{RAC}_{\mathrm{I}}, \mathrm{RAC}_{\mathrm{P}}\right)$, and the capacity to harvest $(\mathrm{CRH})$. These are aggregated in a model under the heading of resource availability (RAV; Fig. 4). Such criteria offer some possibility of measurement but there are also clear qualitative and more subjective elements to consider. The threshold is unlikely to be the same for each harvester, household, or community. For example, a harvester with family illness, e.g., cancer, may have a higher perception of risk in relation to resource quality. Those with access to transportation may experience fewer physical barriers to accessing natural resources than others.
Fig. 4. Social-ecological thresholds of Cree livelihood in the context of increasing resource development. The total value from land use, whether resource development or traditional harvesting, in the Treaty \#8 region is represented on the $y$ axis. A conceptual timeline is shown on the $\mathrm{x}$ axis. (a) Since the signing of Treaty \#8 in 1899, lands have increasingly been alienated away from traditional uses of hunting, fishing, trapping, and related harvesting activities and have been "taken up" (as described in the language of the Treaty) for other uses defined by the state. The heuristic suggests that traditional land use patterns may have been relatively noncompetitive with resource development during the early period of settlement (b-c). However, the capacity of harvesters to sustain such a traditional livelihood was inevitably surpassed (d) with increased development and impacts on resource availability (RAV), which is defined here as a function of resource quality (RQ), physical and institutional access (RAC), with feedbacks on the capacity, i.e., knowledge and skills, for resource harvesting (CRH; ce). $F=R A V\left(R A B, R Q, R_{P}, R A C_{I}\right),(C R H)$.

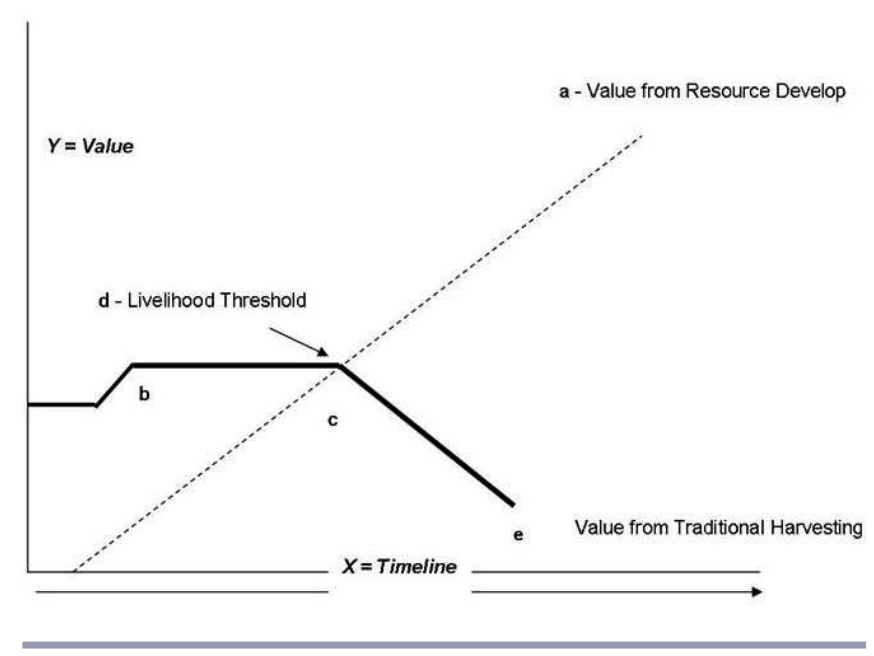

Identifying thresholds after they have been crossed is less problematic than identifying those that might occur in future, as noted by Walker and Meyers (2004). Further research with Cree land users about areas of the Lesser Slave Lake under stress may, however, be predictive of future regime shifts and suggest both opportunities and limits to the adaptability of harvesters. Of particular and growing importance is the impact of declining availability of traditional food sources and the increased prevalence of Type II diabetes among the Lesser Slave Lake Cree and other Aboriginal populations (Oster et al. 2011).

\section{CONCLUSION}

Traditional ecological knowledge was discussed here as a means of understanding the cumulative effects of resource 
development in the Lesser Slave Lake region. In addition to helping reconstruct the history of ecological change in this part of northern Alberta, we assert that TEK may also be useful in identifying past and future shifts in the stability of linked ecological and social systems. Although the evidence in this paper points to social-ecological thresholds in the past, TEK holders may also be attuned to emergent or future regime shifts and be able to predict tipping points better than those whose relationship to the environment is less connected to the security of a healthy resource base (Fazey et al. 2006). As noted by a well-respected elder of Lutsël K'e Dene First Nation, "Some people who don't care so much won't notice the changes" (Parlee et al. 2005:173).

For the Cree of Lesser Slave Lake, the need to understand cumulative effects and thresholds is not a technical exercise; rather it speaks to the viability of their livelihood and that of future generations. The collapse of traditional livelihood practices due to the lack of availability of natural resources, is a circumstance that violates the terms of both Treaty \#8 and the Natural Resources Transfer Agreement (1930). As Alberta prepares for the implementation of its land use framework and seeks to "balance resource development with other social, cultural and ecological values" (Government of Alberta 2010:15) this research points to the harms caused by the marginalization of Aboriginal peoples in land use decisions in the past and the necessity of understanding limits, both social and ecological, in future land use planning decisions. Upholding promises made in the treaty and legislation related to the continuance of traditional livelihood practices will inevitably prove more complex in practice than in principle.

Beyond these regional and provincial resource management purposes, the chronicling of change done by land users from this region is arguably important to individuals and the communities. Faced with rapid pace and scale of development, many elders, adults, and youth in this region arguably struggle to find meaning in what is going on around them, to continue to see their past, their present, and future in a landscape that is irrevocably transformed. More research is needed on the links between changes in environmental conditions and community well-being; more specifically, whether those who continue to observe and experience the environment are more adaptive to what is occurring around them, or have a greater basis of knowledge from which to understand, cope, or adapt to changing and uncertain ecological conditions.

Responses to this article can be read online at: http://www.ecologyandsociety.org/vol17/iss2/art20/ responses/

\section{Acknowledgments:}

The authors would like to thank Edna Willier, the Lesser Slave Lake Indian Regional Council and the participants and communities of the Lesser Slave Lake region. Thanks also to the Sustainable Forest Management Network, the University of Alberta Faculty of Native Studies and Department of Resource Economics and Environmental Sociology, Agricultural, Life and Environmental Sciences, and the Canadian Circumpolar Institute for funding. Maps of the Swan Hills region are included with thanks to Global Forest Watch Canada. We also thank Dr. Mark Stevenson, Dr. Jim Frideres, and Monique Ross for their input and guidance.

\section{LITERATURE CITED}

Agyeman, J., P. Cole, R. Haluza-DeLay, and P. O’Riley, editors. 2009. Speaking for ourselves: environmental justice in Canada. UBC Press, Vancouver, British Columbia, Canada.

Alberta Environmental Protection and Enhancement Act, S. A. 1992, c. E-13.3, s.47(d).

Alberta Sustainable Resource Development. 2003. Detailed forest management plan: Slave Lake Pulp Corporation. Alberta Sustainable Resource Development, Edmonton, Alberta, Canada.

Anielski, M. 2001. Alberta sustainability trends 2000: genuine progress indicators report 1961 to 1999. Pembina Institute for Appropriate Development. Assessment Review 22:111-127.

Banfield, A. W. F. 1974. The mammals of Canada. University of Toronto Press, Toronto, Ontario, Canada.

Baxter, J., and D. Lee. 2004. Understanding expressed low concern and latent concern near a hazardous waste treatment facility. Journal of Risk Research 7(7-8):705-729. http://dx.d oi.org/10.1080/1366987042000146210

Bergerud, A. T. 1974. Decline of caribou in North America following settlement. Journal of Wildlife Management 38 (4):757-770. http://dx.doi.org/10.2307/3800042

Berkes, F. 1982. Waterfowl management and northern Native peoples with reference to Cree hunters of James Bay. MuskOx 30:23-35.

Berkes, F. 2008. Sacred ecology. Routledge Press, Toronto, Ontario, Canada.

Berkes, F., J. Colding, and C. Folke, editors. 2001. Navigating social-ecological systems: building resilience for complexity and change. Cambridge University Press, New York, New York, USA. http://dx.doi.org/10.1017/CBO9780511541957

Berkes, F., and M. Kislalioglu Berkes. 2009. Ecological complexity, fuzzy logic, and holism in indigenous knowledge. Futures 41(1):6-12. http://dx.doi.org/10.1016/j.futures.2008.07.003 
Bill, L., J. Crozier, and D. Surrendi. 1996. A report of wisdom synthesized from the traditional knowledge component studies: northern river basins study. Government of Alberta, Edmonton, Alberta, Canada.

Dana, L. P., R. B. Anderson, and A. Meis-Mason. 2009. A study of the impact of oil and gas development on the Dene First Nations of the Sahtu (Great Bear Lake) Region of the Canadian Northwest Territories (NWT). Journal of Enterprising Communities: People and Places in the Global Economy 3(1):94-117. http://dx.doi.org/10.1108/1750620091 $\underline{0943706}$

Fazey, I., K. Proust, B. Newell, B. Johnson, and J. A. Fazey. 2006. Eliciting the implicit knowledge and perceptions of onground conservation managers of the Macquarie Marshes. Ecology and Society 11(1): 25. [online] URL: http://www.eco logyandsociety.org/vol11/iss1/art25/

Finlayson, B. L., and S. O. Brizga. 1995. The oral tradition, environmental change and river basin management: case studies from Queensland and Victoria. Australian Geographical Studies 33(2):180-192. http://dx.doi.org/10.1111/ j.1467-8470.1995.tb00693.x

Government of Alberta. 2003. Water management plan for Lesser Slave Lake and Lesser Slave River Basins - Phase 1. Department of Sustainable Resource Development, Edmonton, Alberta, Canada. [online] URL: http://www3.gov. ab.ca/env/water/regions/lsb/pubs/LSL RBtor.pdf

Government of Alberta. 2010. Land use framework. Department of Sustainable Resource Development, Edmonton, Alberta, Canada.

Gummer, W. D., K. J. Cash, F. J. Wrona, and T. D. Prowse. 2000. The northern river basins study: context and design. Journal of Aquatic Ecosystem Stress and Recovery 8:7-16. http://dx.doi.org/10.1023/A:1011431503940

Johannes, R. E., and H. T. Lewis. 1993. The importance of researchers' expertise in environmental subjects. In N. M. Williams and G. Baines, editors. Traditional ecological knowledge: wisdom for sustainable development. Australian National University, Canberra, Australia.

Kennett, S. A. 1999. Towards a new paradigm for cumulative effects management. CIRL Occasional Paper No. 8, Canadian Institute of Resources Law, Calgary, Alberta, Canada.

Lane, R. 1997. Oral histories and scientific knowledge in understanding environmental change: a case study in the Tumut Region, NSW. Australian Geographical Studies 35 (2):195-205. http://dx.doi.org/10.1111/1467-8470.00019

Mair, C. 1999. Through the Mackenzie Basin: an account of the signing of Treaty No. 8 and the Scrip Commission: Treaty at Lesser Slave Lake (1899). University of Alberta Press, Edmonton, Alberta, Canada.
McLoughlin, P. D., E. Dzus, B. Wynes, and S. Boutin. 2003. Declines in populations of woodland caribou. Journal of Wildlife Management 67(4):755-761. http://dx.doi.org/10.230 7/3802682

Mitchell, P., and E. E. Prepas. 1990. Atlas of Alberta Lakes. University of Alberta Press, Edmonton, Alberta, Canada.

Nakashima, D. 1990. Application of Native knowledge in EIA: Inuit Elders and Hudson's Bay Oil. Canadian Museum of Nature, Ottawa, Ontario, Canada.

Natcher, D. C., and C. G. Hickey. 2002. Putting the community back into community-based resource management: a criteria and indicators approach to sustainability. Human Organization 61(4):350-363.

Nielsen, S. E., G. B. Stenhouse, and M. S. Boyce. 2006. A habitat-based framework for grizzly bear conservation in Alberta. Biological Conservation 130:217-229. http://dx.doi. org/10.1016/j.biocon.2005.12.016

Ommer, R., and the Coasts Under Stress Research Team. 2007. Coasts under stress: restructuring and social-ecological health. McGill-Queens University Press, Montreal, Quebec, Canada.

Omura, K. 2002. Construction of Inuinaqtun (real Inuit way): self image and everyday practices in Inuit society. In H. Stuart, A. Bernard, and K. Omura, editors. Self and other images of hunter gatherers. Senri Ethnological Studies 60:101-111.

Oster, R. T., J. A. Johnson, B. R. Hemmelgarn, M. King, S. U. Balko, L. W. Svenson, L. Crowshoe, and E. Toth. 2011. Recent epidemiologic trends of diabetes mellitus among status Aboriginal adults. Canadian Medical Association Journal 183 (12):E803-E808. http://dx.doi.org/10.1503/cmaj.101882

Parlee, B., M. Manseau, and Lutsël K'e Dene First Nation. 2005. Understanding and communicating about ecological change: Denesoline indicators of ecosystem health. Pages 165-182 in F. Berkes, R. Huebert, H. Fast, M. Manseau, and A. Diduck, editors. Breaking ice: renewable resource and ocean management in the Canadian North. University of Calgary Press, Calgary, Alberta, Canada.

Poirer, S., and L. Brooke. 2000. Inuit perceptions of contaminants and environmental knowledge in Salluit, Nunavik. Arctic Anthropology 37(2):78-91.

Ryder, R. A. 1965. A method for estimating the potential fish production of north-temperate lakes. Transactions of the American Fisheries Society 94:214-218. http://dx.doi.org/10. 1577/1548-8659(1965)94[214:AMFETP]2.0.CO;2

Sallenave, J. 1994. Giving traditional knowledge its rightful place in environmental assessment. Northern Perspectives 22 (1):16-19. 
Schneider, R. R., J. B. Stelfox, S. Boutin, and S. Wasel. 2003. Managing the cumulative impacts of land uses in the western Canadian sedimentary basin: a modeling approach. Conservation Ecology 7(1): 8. [online] URL: http://www.eco logyandsociety.org/vol7/iss $1 /$ art8/

Scott, W. B., and E. J. Crossman. 1973. Freshwater fishes of Canada. Fisheries Research Board of Canada Bulletin, Fisheries and Oceans Canada, Ottawa, Ontario, Canada.

Smith, J. G. E. 1981. Western Woods Cree. In J. Helm, editor. Handbook of North American Indians, Vol.6: Subarctic. Smithsonian Institute, Washington, D.C., USA.

Smith, J. G. E. 1987. The Western Woods Cree: anthropological myth and historical reality. American Ethnologist 14:434-448. http://dx.doi.org/10.1525/ae.1987.14 $.3 .02 \mathrm{a} 00020$

Stevenson, M. G., and D. C. Natcher, editors. 2010. Planning for co-existence: Aboriginal approaches to land use planning in Canada. Canadian Circumpolar Institute Press, Edmonton, Alberta, Canada.

Stuart-Smith, A. K., C. J. A. Bradshaw, S. Boutin, D. M. Hebert, and A. B. Rippin. 1997. Woodland caribou relative to landscape patterns in northeast Alberta. Journal of Wildlife Management 61(3):622-633. http://dx.doi.org/10.2307/3802170

Tenenbaum, D. J. 2009. Oil sands development: a health risk worth taking? Environmental Health Perspectives 117:150-156. http://dx.doi.org/10.1289/ehp.117-a150

Thormann, M. N., M. Logan, and M. Gray. 2008. Source water protection plan for the Driftpile First Nation. Aquality Environmental Consulting, Edmonton, Alberta, Canada.

Timoney, K., and P. Lee. 2001. Environmental management in resource-rich Alberta, Canada: first world jurisdiction, third world analogue? Journal of Environmental Management 63 (4):387-405. http://dx.doi.org/10.1006/jema.2001.0487

Tough, F. 2003. The forgotten constitution: the Natural Resources Transfer Agreements and Indian livelihood rights 1925-1935. Alberta Law Review 41:999-1048.

Tupper, A., L. Pratt, and I. Urquhart. 1992. The role of government. Pages 31-66 in A. Tupper and R. Gibbons, editors. Government and Politics in Alberta. University of Alberta, Edmonton, Alberta, Canada.

Usher, P. J., P. Cobb, M. Loney, and G. Spafford. 1992. Hydroelectric development and the English River Anishanabe: Ontario Hydro's past record and present approaches to treaty and Aboriginal rights, social impact assessment and mitigation and compensation. Report for Nishanawbe Aksi Nation: Grand Council Treaty 3 and Tema-Augama Anishanabai. Usher Consulting, Ottawa, Ontario, Canada.
Vanderhill, B. G. 1963. Trends in the Peace River country. Canadian Geographer 7(1):33-41. http://dx.doi.org/10.1111/ j.1541-0064.1963.tb00310.x

Walker, B., and J. A. Meyers. 2004. Thresholds in ecological and social-ecological systems: a developing database. Ecology and Society 9(2): 3. [online] URL: http://www.ecologyandso ciety.org/vol9/iss $2 /$ art3/

Witt, N., and J. Hookimaw-Witt. 2010. Pinpinayhatosowin (the way we do things): a definition of traditional ecological knowledge (TEK) in the context of mining development on lands of the Attawapiskat First Nation and its effects on the design of research for a TEK study. Canadian Journal of Native Studies 23(2):361-390. 